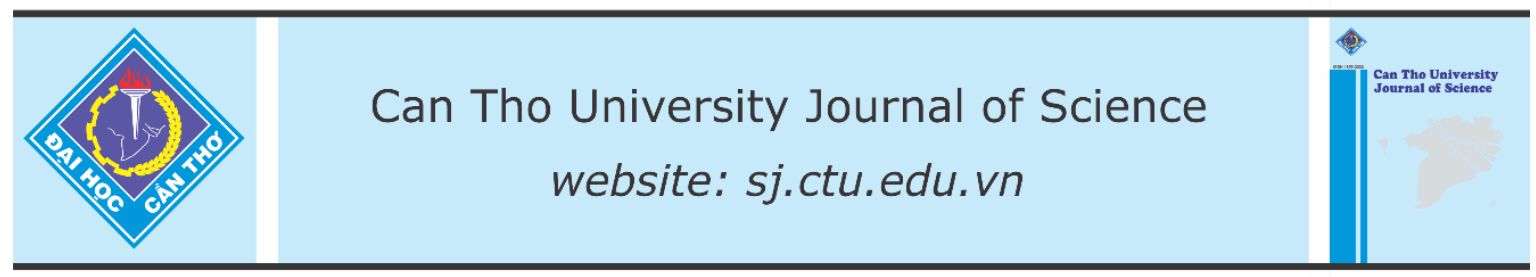

DOI: 10.22144/ctu.jen.2021.021

\title{
Characterizations of sulfur oxidizing bacteria from extensive shrimp ponds
}

\author{
Huynh Truong Giang*, Vu Hung Hai, Phan Thi Cam Tu, Pham Thi Tuyet Ngan and Vu Ngoc Ut \\ College of Aquaculture and Fisheries, Can Tho University, Viet Nam \\ *Correspondence: Huynh Truong Giang (email: htgiang@ctu.edu.vn)
}

\section{Article info.}

Received 22 Feb 2021

Revised 15 Apr 2021

Accepted 04 Jun 2021

\section{Keywords}

Autotrophic, extensive shrimp ponds, probiotic, sulfur oxidizing bacteria, thiosulfate medium

\begin{abstract}
The aim of this study is to characterize the sulfur oxidizing bacteria (SOB) isolates from the sediments of extensive shrimp ponds for recommending the use of this group for water quality management in aquaculture. Sediment samples were collected from 12 extensive shrimp ponds located in Tra Vinh, Soc Trang, Bac Lieu, and Ca Mau provinces. To screen the potential sulfur oxidizing bacteria, medium was amended with sodium thiosulfate, and the sulfate ion production ability and sulfur oxidase enzyme activity of the isolates were measured spectrophotometrically. Results showed that 30 isolates grew on the thiosulfate agar medium. Among these, only five isolates reduced the $\mathrm{pH}$ of the growth medium and showed high sulfur oxidase activity and production of sulfate ion when isolates were inoculated with thiosulfate as a substrate. Physiological and biochemical tests indicated that five selected isolates were Gram negative, short rod, non-motile, non-spore forming, negative for oxidase reaction, and positive for catalase reaction. The isolates SOBTB1.1 and SOBTB6.2 showed the significantly higher sulfur oxidase activity and production of sulfate ion compared to other isolates. SOBTB6.2 isolate produced sulfate ion and exhibited higher sulfur oxidase activity at pH4-5, followed by $\mathrm{pH6}$-7. It is, therefore, suggested that the SOBTB 1.1 and SOBTB6.2 could be promising sulfur oxidizers for further research and uses in aquaculture.
\end{abstract}

\section{INTRODUCTION}

Aquaculture has been growing and expanding very rapidly in recent years. In 2018, global fish production is estimated to have reached about 179 million tons, of which 82.1 million tons came from aquaculture. Among major species, whiteleg shrimp production was accounted for 4.97 million tons (Food and Agriculture Organization [FAO], 2020). In Vietnam, according to the Vietnam Association of Seafood Exporters and Producers (VASEP, 2020), the shrimp culture area in 2019 reached 720,000 ha and whiteleg shrimp production was estimated about 480,000 tons.
In recent years, intensification of shrimp culture in the Mekong Delta has been pressured with seed quality, diseases outbreak, and poor water quality. In shrimp culture ponds, the organic matters are normally high due to extraneous inputs such as feed, excreta, and fertilizers. The microorganisms such as bacteria, fungi, and protozoa, carry out active decomposition of leftover feed and metabolites to inorganic forms through the process of mineralization (Moriarty, 1997). The decomposition of proteins of organic matter leads to the increase of unionized hydrogen sulfide $\left(\mathrm{H}_{2} \mathrm{~S}\right)$ that is considered toxic and causes massive mortalities in aquaculture ponds (Chien, 1992). Chen (1985) recommended a safe level of $0.033 \mathrm{mg} / \mathrm{L}$ for black tiger shrimp, Penaeus 
monodon while Boyd (1998) recommended that the level of $\mathrm{H}_{2} \mathrm{~S}$ for aquaculture should be at not detectable level. Hence, maintaining low concentration of $\mathrm{H}_{2} \mathrm{~S}$ in rearing pond is of the most concerns.

Water quality is linked to the microbial activities in aquaculture systems. Microbial processes affect water quality factors such as dissolved oxygen, ammonia $\left(\mathrm{NH}_{3}\right)$, nitrite $\left(\mathrm{NO}_{2}^{-}\right)$and $\mathrm{H}_{2} \mathrm{~S}$ (Moriarty, 1997). Therefore, beneficial bacteria have been introduced as an alternative strategy for maintaining good water quality. When added to the culture water, some beneficial bacteria act as so-called bioremediation agents by improving water quality and pond conditions while minimizing environmental degradation. At present, a diverse range of beneficial bacteria has been used as probiotics in aquaculture such as $\mathrm{Ba}$ cillus, Lactobacillus, Enterococcus, Pediococcus, Lactococcus, Bifidobacterium, Streptococcus, Thiobacillus, Nitrobacter, Nitrosomonas, Photorhodobacterium (Jahangiri \& Esteban, 2018; Mayer et al., 2020).

In pond bottom sediment, $\mathrm{SO}_{4}{ }^{2-}$ and $\mathrm{H}_{2} \mathrm{~S}$ are constantly recycled between oxidation and reduction steps, predominantly carried out by sulfate reducing bacteria (SRB) and sulfur oxidizing bacteria (SOB) (Fry, 1987). Sulfur oxidizing bacteria, also known as colorless sulfur bacteria, are ubiquitous in aquatic environment. $\mathrm{H}_{2} \mathrm{~S}$ is a source of electrons for these bacteria under aerobic and anaerobic (Forte \& Giuffre, 2016). Sulfur oxidizing bacteria are able to metabolize sulfide to sulfate which is nontoxic (as cited in Nadella et al., 2019) to aquatic animals. Sulfur oxidizing bacteria have been isolated for removal of $\mathrm{H}_{2} \mathrm{~S}$ in the activated sludge bioreactor (Barbosa et al., 2006), biotrickling filters (Aroca et al., 2007), or removal of heavy metals from activated sludge $(\mathrm{Li}$ et al., 2012). In aquaculture, few studies were carried out to enumerate or to isolate these bacteria from various aquaculture systems (Abraham et al., 2004; 2015; Krishnani et al., 2010; Jaffer et al., 2019; Nadella et al., 2019). However, characteristics of SOB in shrimp ponds in the Mekong Delta have received less attention. Therefore, this study aimed to isolate and characterize the sulfur oxidizing bacteria from bottom sediment of shrimp pond to serve as a base for recommending use of these bacteria for water treatment in aquaculture.

\section{MATERIALS AND METHODS}

\subsection{Collection of soil samples}

Sediment samples were collected from extensive shrimp ponds located in Tra Vinh, Soc Trang, Bac Lieu and $\mathrm{Ca}$ Mau provinces. Three ponds were selected in each province. The extensive shrimp ponds selected based on the characterization of low stocking density and relied on natural food (Brennan et al., 2000; Oddsson, 2020). At each pond, top 3-cm sediment layer was collected using a device as described by Somsiri et al. (2006). Samples at 5 points in pond were mixed vigorously, and around $20 \mathrm{~g}$ of sample were placed in aseptic sample bags with proper labeling and transported to the laboratory in ice box and then stored at $4^{\circ} \mathrm{C}$ for further bacterial isolation. All procedures of isolation and characterization of bacteria were performed at the Laboratory for Beneficial Bacteria in Aquaculture, Department of Applied Hydrobiology, College of Aquaculture and Fisheries, Can Tho University, Vietnam.

\subsection{Culture medium}

Thiosulfate medium (TSM) contains $(\mathrm{g} / \mathrm{L}): 1.5 \mathrm{~g}$ $\mathrm{K}_{2} \mathrm{HPO}_{4}, \quad 1.5 \mathrm{~g} \quad \mathrm{KH}_{2} \mathrm{PO}_{4}, 0.4 \mathrm{~g} \quad \mathrm{NH}_{4} \mathrm{Cl}, 0.8 \mathrm{~g}$ $\mathrm{MgCl}_{2} \cdot 6 \mathrm{H}_{2} \mathrm{O}, 0.1 \mathrm{~g} \mathrm{CaCl} 2.2 \mathrm{H}_{2} \mathrm{O}$ and $10 \mathrm{~g}$ of $\mathrm{Na}_{2} \mathrm{~S}_{2} \mathrm{O}_{3} .5 \mathrm{H}_{2} \mathrm{O}$. For plating, the plates were prepared with the addition of agar $(15 \mathrm{~g} / \mathrm{L})(\mathrm{BD}$ Difco, India).

\subsection{Enrichment and isolation}

Sulfur oxidizing bacteria were activated under aerobic condition in a $100 \mathrm{~mL}$-Erlenmeyer. One gram of sediment sample was added to the $20 \mathrm{~mL}$ of TSM (containing $1 \% \mathrm{NaCl}$ ) and kept in orbital shaker at $160 \mathrm{rpm}$ and $20^{\circ} \mathrm{C}$ for 7 days. After activation period, media was replaced by fresh media. The process was repeated for five transformations in order to ensure the suppression of growth of any anaerobic bacteria in the sludge and to activate only sulfide oxidizing bacteria. One hundred microliters of portions were spread on triplicate plates of TSM $(1.5 \%$ agar $+1 \% \mathrm{NaCl}$ ), and then incubated at $28^{\circ} \mathrm{C}$ for 168 hours. After 168 hours of incubation, well defined isolated colonies were randomly picked and streaked onto TSM plates to check for purity. The process was repeated for 3 times in order to get pure cultures of sulfur-oxidizing bacteria (Ravichandra et al., 2007). For quality screening, the isolates were grown in the TSM broth with addition of bromocresol purple $(10 \mathrm{mg} / \mathrm{L})$ as an indicator for monitoring the $\mathrm{pH}$ changes of the medium from purple to yellow during 168 hours (Ullah et al., 2013). Bacterial isolates with ability to lower the $\mathrm{pH}$ of the broth were selected and preserved in glycerol at $-80^{\circ} \mathrm{C}$ for further studies. 


\subsection{Characterizations of the bacterial isolates}

Bacterial isolates in this study were identified as per standard method according to Bergey's Manual of Determinative Bacteriology (Brenner et al., 2005). The bacterial isolates were presumptively identified by means of morphological examination (shape, spore and motility), staining reaction (Gram's reaction) and biochemical tests (catalase production, oxidase production), thiosulfate utilization. In addition, sulfur-oxidase activity of isolates was also examined.

\section{Cell and colony morphology}

Gram staining was done, and the morphology of the isolates was observed under a microscope. For colony characterization TSM agar medium (pH8.0), the isolates were plated in sterile Petri dishes by the pour plate method and the plates were incubated at $28^{\circ} \mathrm{C}$ for 168 hours. Colony characters were recorded after the incubation period.

\section{Gram's staining}

Gram's staining was performed on a glassslide from a single bacterial colony by crystal violet, iodine, and safranin solutions. The slide was washed properly by running tap water before the start of the next step. The slide image analyses were performed usinga light microscope; gram-negative cells were stained pink (Hucker \& Conn, 1923). Concurrently, Gram type of bacterial isolates were also confirmed by nonstaining $(\mathrm{KOH})$ method (Buck, 1982, as cited in Cheng et al., 2016). Briefly, the reaction was conducted by adding few drops of $3 \% \mathrm{KOH}$ on the bacterial isolates. If the bacterium- $\mathrm{KOH}$ suspension becomes markedly viscid or gels within 5 to $60 \mathrm{sec}-$ onds, the isolate is gram negative. If no gelling is observed, the isolate is gram positive.

\section{Catalase test}

A clean glass slide was taken, and a drop of culture suspension was placed on the glide. To the culture few drops of hydrogen peroxide was added. A positive reaction indicates the release of air bubbles from the suspension. This enzyme detoxified hydrogen peroxide by breaking it down into water and $\mathrm{O}_{2}$ gas (Reiner, 2018).

\section{Oxidase test}

Firstly, small piece of filter paper was soaked in $1 \%$ Tetramethyl- $p$-Phenylendiamin dihydrochloridand dried. Subsequently, a well-isolated colony from bacterial plate was picked using a loop, and then bacteria were rubbed onto the treated filter paper.
Bacteria are oxidase positive when the color changes to dark purple within 5 to 10 seconds or when the color changes to purple within 60 to 90 seconds, whereas bacteria are oxidase negative if the color does not change or it takes longer than 2 minutes (Shields \& Cathcart, 2018).

\section{Determination of bacterial motility}

The motility of the test strain was tested by the hanging-drop method. A loopful of bacteria isolate was mixed with a drop of sterile distilled water on the microscope slide. The mixture was covered with a cover glass, and then examined microscopically using the $100 \mathrm{X}$ objective.

\section{Sulfate ion production}

Sulfate production resulting from bacterial growth was observed by measuring the initial and the final sulfate concentration of the culture broth. Bacterial broth culture was centrifuged at $10,000 \mathrm{rpm}$ and $4^{\circ} \mathrm{C}$ for $5 \mathrm{~min}$ to remove the bacterial cells (Nadella et al., 2019). The cell free supernatant (CFS) was used for determination of sulfate ion according to the turbidimetric method 4500- $\mathrm{SO}_{4}{ }^{2-} \mathrm{E}$ (American Public Health Association [APHA] et al., 2017). For this, sulfate ion was precipitated in an acetic acid medium with barium chloride $\left(\mathrm{BaCl}_{2}\right)$ to form barisulfate $\left(\mathrm{BaSO}_{4}\right)$. The suspension was shaken vigorously and measured with a spectrophotometer (Helios Alpha, Thermofisher Scientific, USA) at 420 $\mathrm{nm}$ using $1 \mathrm{~cm}$-glass cuvettes. The amount of sulfate formed as calculated from sulfate standard curve which prepared by dissolving known concentrations of sodium sulfate in deionized water.

\section{Sulfur oxidation assay}

The method for sulfur oxidase activity was based on Hirano et al. (1996) and Nadella et al. (2019) with slight modifications. The sulfide-oxidizing activity of SOB isolates cells were determined by measuring the increase in sulfate concentration in a reaction mixture. The composition of the reaction mixture $(6.0 \mathrm{~mL})$ was as follows: $1.0 \mathrm{~mL}$ of cell suspension; $4.5 \mathrm{~mL}$ of $0.1 \mathrm{M}$ sodium acetate buffer; and $0.5 \mathrm{~mL}$ $\mathrm{Na}_{2} \mathrm{~S}$ solution $\left(0.06 \mathrm{~g} \mathrm{Na}_{2} \mathrm{~S}, 0.16 \mathrm{~g} \mathrm{NaOH}, 0.02 \mathrm{~g}\right.$ EDTA $\mathrm{Na}_{2} .2 \mathrm{H}_{2} \mathrm{O}, 2 \mathrm{~mL}$ glycerol and $40 \mathrm{~mL}$ of deionized water). The reaction was done in a $16-\mathrm{ml}$ tube. The reaction mixture was then incubated at $30^{\circ} \mathrm{C}$ for $30 \mathrm{~min}$. The reaction was terminated by adding $1.5 \mathrm{~mL}$ of $1 \mathrm{M} \mathrm{NaOH}$. The cells were removed by centrifuging at $10,000 \mathrm{rpm}$ and $4^{\circ} \mathrm{C}$ for 5 min. The supernatant was used for determination of sulfate ion. The method for sulfate ion analysis was as mentioned above. The enzyme oxidase activity 
(U) was defined as the amount required producing $1 \mu \mathrm{mol}$ sulfate $/ \mathrm{h} / \mathrm{mL}(\mathrm{U} / \mathrm{mL})$. For blank, bacterial supernatant was replaced with $0.1 \mathrm{M}$ sodium acetate buffer. Each sample was run in triplicate.

Sulfur-oxidase activity $(\mathrm{U} / \mathrm{mL})=$

$$
\frac{(\text { SulfateSOB }- \text { SulfateControl) } \times 1000}{0.5 \mathrm{~h} \times 32 \times 6 \mathrm{~mL}}
$$

The isolate with the highest sulfate ion production and sulfide oxidase activity was used for further test to unravel if $\mathrm{pH}$ affecting sulfate ion production and sulfide oxidase activity of the selected SOB.

\subsection{Data analysis}

Statistical analyses were performed using SAS version 9.4 (SAS Institute, Cary, NC, USA). One-way analysis of variance (ANOVA) was used to identify differences among treatments followed by Tukey's HSD multiple comparisons test to determine differences among groups. Alpha was set to 0.05 for all statistical comparisons.
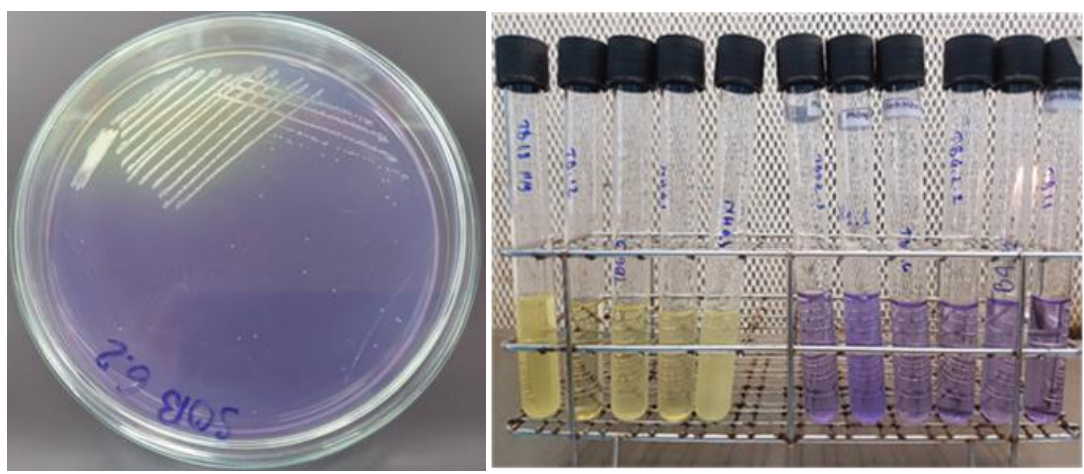

Figure 1. Reduction of pH in the growth media by SOB

\subsection{Physico-biochemical traits}

\subsubsection{Morphology, motility, and oxidase and catalase production}

All the selected isolates were Gram negative, short rod, non-motile, non-spore forming (Figure 2). All the isolates were negative for oxidase, but positive for catalase (Table 1). Chemolithotrophic aerobic growths of isolates were found on sulfide-containing medium. In addition, the isolates also grew under anaerobic conditions with presence of sodium thiosulfate after 168 hours of incubation at $28^{\circ} \mathrm{C}$.

\section{RESULTS}

\subsection{Isolation and selection of SOB}

A total of 30 isolates was obtained from sediment of extensive shrimp ponds and grew on the TSM plates. After quality screening for pure cultures, only 5 isolates were able to oxidize sulfide resulting in lowering $\mathrm{pH}$ that was observed as a change in the color of the medium surrounding the colonies from purple to yellow and this phenomenon was also confirmed in the TSM broth containing Bromocresol purple (Figure 1). Four isolates produced round smooth and raised white-opaque colonies on the TSM agar plate, while only one isolate was smooth, straw yellow color colonies. The average diameters of colonies were in a range of 0.5-1.0 mm. Based on the removal of sulfide as mentioned above, the isolates as SOBTB1.1, SOBTB4.1, SOBTB6.2, SOBTB1.4, and SOBTB2.4 were selected for further characterization.

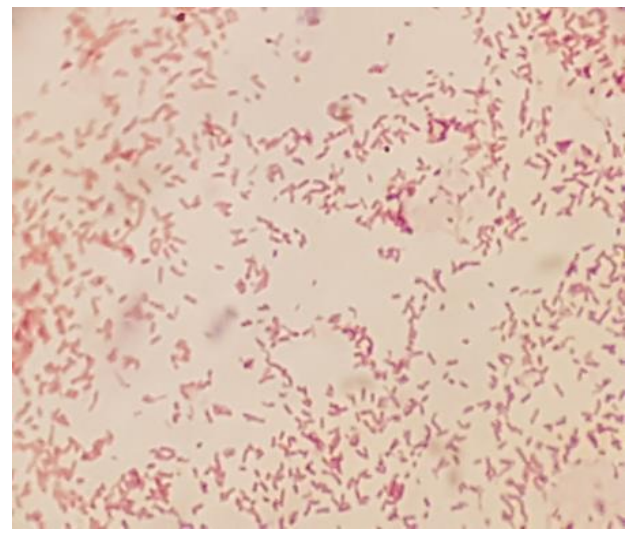

Figure 2. Gram reaction of selected SOB 
Table 1. Properties of the screened SOB isolated from shrimp ponds

\begin{tabular}{lccccc}
\hline Isolate & TB 1.1 & TB 4.1 & TB 6.2 & NH 1.4 & NH 2.4 \\
\hline Morphology & Short rod & Short rod & Short rod & Short rod & Short rod \\
Gram reaction & Negative & Negative & Negative & Negative & Negative \\
Catalase production & + & + & + & + & + \\
Oxidase production & - & - & - & - & - \\
Motility & - & - & - & - & - \\
Spore forming & - & - & - & - & - \\
Temperature optimum $\left({ }^{\circ} \mathrm{C}\right)$ & 30 & 30 & 30 & 30 & 30 \\
pH range for growth & $4.0-9.0$ & $4.0-9.0$ & $4.0-9.0$ & $4.0-9.0$ & $4.0-9.0$ \\
$\mathrm{H}_{2}$ S production & - & - & - & - & - \\
Glucose utilization & - & - & - & - & - \\
\hline
\end{tabular}

Table 2. Differentiation of the genera of chemolithotrophic, sulfur-oxidizing, rod-shaped bacteria according to Bergey's Manual of Determinative Bacteriology for SOB (Kelly et al., 2005)

\begin{tabular}{lccrcc}
\hline Character & $\begin{array}{c}\text { Obligate } \\
\text { Chemolitho- } \\
\text { autotroph }\end{array}$ & $\begin{array}{c}\text { Heterotrophic } \\
\text { growth on de- } \\
\text { fined media }\end{array}$ & $\begin{array}{c}\text { Optimal } \\
\text { tempera- } \\
\text { ture }\left({ }^{\circ} \mathbf{C}\right)\end{array}$ & $\begin{array}{c}\text { Optimal } \\
\text { pH }\end{array}$ & $\begin{array}{c}\text { Contains photo- } \\
\text { synsynthetic reac- } \\
\text { tion center }\end{array}$ \\
\hline Thiobacillus & + & - & $28-43$ & $6.8-8.0$ & - \\
Acidiphilium & - & + & $25-37$ & $3.3-3.5$ & + \\
Acidithiobacillus & + & - & $30-45$ & $2.0-3.5$ & - \\
Halothiobacillus & + & - & $28-30$ & $6.5-8.0$ & - \\
Paracoccus & - & + & $25-37$ & $6.5-9.0$ & - \\
Starkeya & - & + & $25-30$ & 7.0 & - \\
Thermithiobacillus & + & - & $43-45$ & $6.8-7.5$ & - \\
Thiomonas & - & - & $30-50$ & $5.2-6.0$ & - \\
\hline
\end{tabular}

\subsubsection{Sulfate ion production}

During growth of SOB, the amount of sulfate ion $\left(\mathrm{SO}_{4}{ }^{2-}\right)$ produced is shown in Figure 3. The isolate SOBTB6.2 showed the highest $\mathrm{SO}_{4}{ }^{2-}$ ion production
$(16.0 \mathrm{mg} / \mathrm{mL})$, followed by isolate SOBTB1.1 (11.4 $\mathrm{mg} / \mathrm{L})$. No significant difference in $\mathrm{SO}_{4}{ }^{2-}$ ion production was observed among isolates SOBNH1.4, SOBNH2.4, and SOBTB4.1 ( $p>0.05)$.

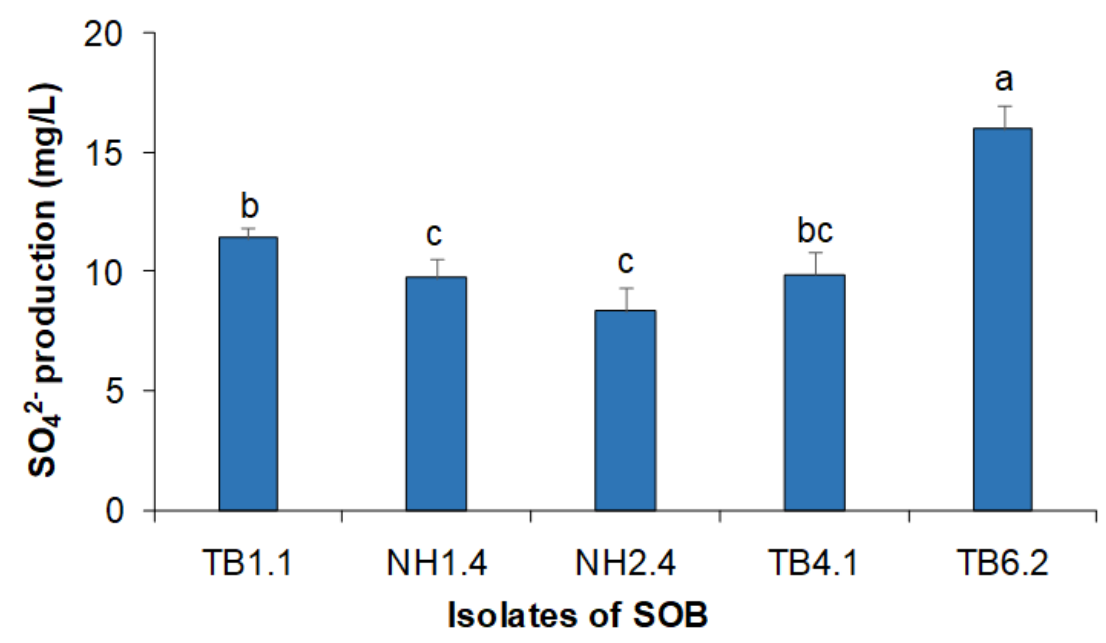

Figure 3. Sulfate ion production produced by the five sulfure oxidizing isolates in the medium

Each bar represents the mean value with the standard deviation. Data with different letters significantly differ $(p<0.05)$ among treatments 


\subsubsection{Sulfide oxidase activity}

The sulfide oxidase activity of five bacterial isolates is shown in Figure 4. Sulfide oxidase activities of SOB isolates ranged from 5.75-8.34 Units/mL. The

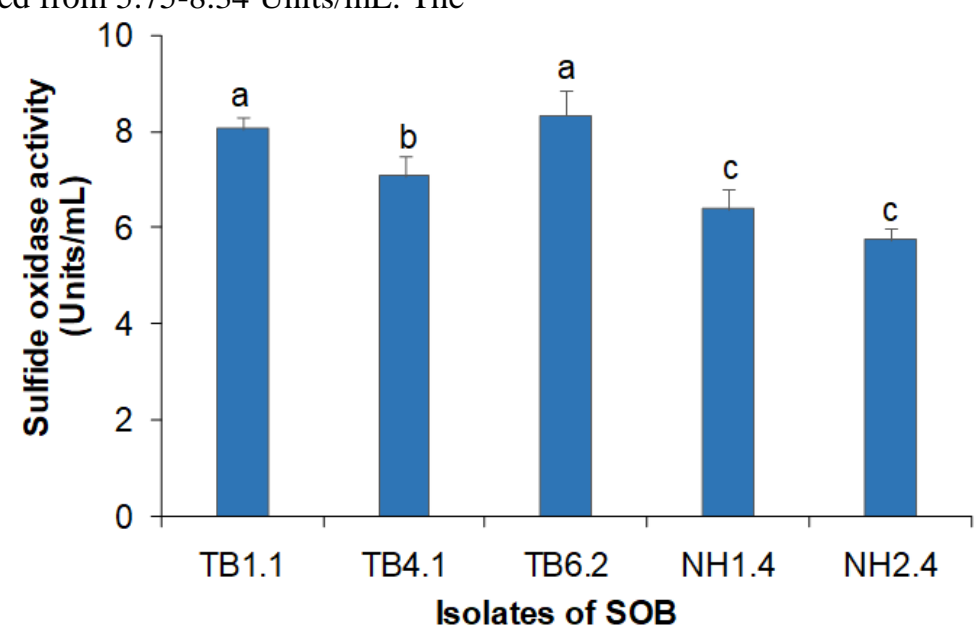

Figure 4. Sulfide oxidase activity of five sulfur oxidizing bacterial isolates

Each bar represents the mean value with the standard deviation. Data with different letters significantly differ $(p<0.05)$ among treatments

\subsubsection{Effects of $\mathrm{pH}$ on sulfate ion production and sulfide oxidase activity}

The obtained results revealed that isolate SOBTB6.2 had the highest sulfate ion production and sulfide oxidase activity. Therefore, the isolate SOBTB6.2 was selected for further examination. Sulfide oxidase activity and sulfate ion production of isolate SOBTB6.2 decreased with increasing $\mathrm{pH}$ isolates SOBTB1.1 and SOB6.2 showed significantly higher sulfide oxidase activity than those of the other isolates. The lowest sulfide oxidase activities found in SOBNH1.4 and SOBNH2.4 isolates.

of medium (Figure 5). The isolate SOBTB6.2 showed the highest sulfide oxidase activity and sulfate ion production when they were cultured in medium with $\mathrm{pH}$ value ranging from 4-5, followed by that cultured at $\mathrm{pH}$ varied from 6-7. The isolate SOBTB6. 2 cultured in medium with $\mathrm{pH} 9.0$ had significant decreases in sulfate ion production and sulfide oxidase enzyme activity than those in $\mathrm{pH}$ 4-7 $(\mathrm{p}<0.05)$.

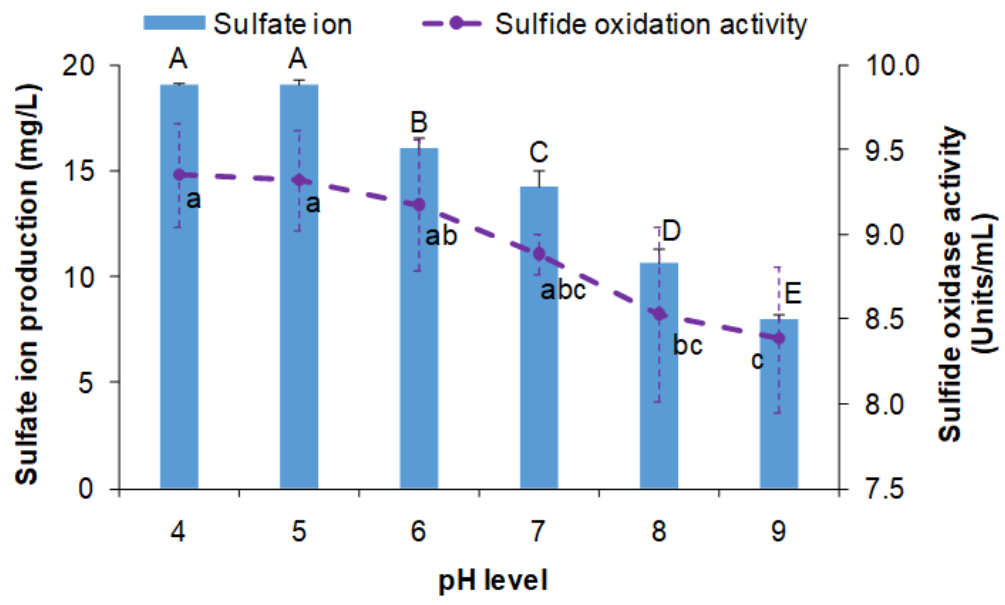

Figure 5. Effect of $\mathbf{p H}$ on sulfate ion production and sulfide oxidase enzyme activity

Each data represents the mean value with the standard deviation. Data with different lower letters $(a, b, c .$.$) or upper$ letters $(A, B, C \ldots)$ significantly differ $(p<0.05)$ among treatments 


\section{DISCUSSIONS}

In water, hydrogen sulfide exists in unionized $\left(\mathrm{H}_{2} \mathrm{~S}\right)$ and ionized forms ( $\mathrm{HS}^{-}$and $\mathrm{S}^{2-}$ ). Only the unionized form $\left(\mathrm{H}_{2} \mathrm{~S}\right)$ is considered toxic to aquatic organisms. Chen (1985, as cited in Chien, 1992) recommended a safe level of $0.033 \mathrm{mg} / \mathrm{L}$ for black tiger shrimp culture while Boyd (1982, as cited in Chien, 1992) suggested a safe level of $0.002 \mathrm{mg} / \mathrm{L} \mathrm{H}_{2} \mathrm{~S}$ for freshwater fish. In pond aquaculture, $\mathrm{H}_{2} \mathrm{~S}$ can be removed by aeration via diffusion or controlling $\mathrm{pH}$ because proportion of total sulfide in $\mathrm{H}_{2} \mathrm{~S}$ increases as $\mathrm{pH}$ falls (Boyd, 2015). Development of the promising strategies for management of toxic gases is ultimately desired during farming operations, in which application of microbial has been of considerations.

Lilly and Stillwell (1965) initially defined probiotics as "growth promoting factors produced by microorganisms". Fuller (1989) revised the definition as "live microbial feed supplement which beneficially affects the host animal by improving its intestinal microbial balance". A more recent, but probably not the last definition is "Live microorganisms which when administered in adequate amounts confer a health benefit on the host" (Guarner \& Schaafsma, 1998). However, Moriarty (1998) proposed to extend the definition of probiotics in aquaculture to microbial "water additives". Hence, the desired characteristics of probiotics are (i) containing live microorganisms, and (ii) providing an adequate dose to exert the desirable effects.

At present, numerous beneficial bacteria have been applied in aquaculture as water additives such as $B a$ cillus, Lactobacillus, Photorhodobacterium, Pseudomonas, Nitrobacter, Nitrosomonas, and Thiobacillus (Jahangiri \& Esteban, 2018; Mayer et al., 2020). Among SOB species, several studies reported that Thiobacillus thioparus showed positive effect on $\mathrm{H}_{2} \mathrm{~S}$ in activated sludge bioreactor during wastewater treatment (Barbosa et al., 2006). In addition, Thiobacillus thioparus and Acidithiobacillus have been successfully applied for removal of hydrogen sulfidein biotrickling filters (Aroca et al., 2007). Kantachote et al. (2008) revealed that selected SOBT307 was able to remove $\mathrm{H}_{2} \mathrm{~S}$ by $86.7 \%$ in vitro and promised as a strain for sulfide treatment biogas systems. However, selection of indigenous SOB for probiotic candidates has received less attention in previous studies in aquaculture.

In aquaculture, populations of SOB in bottom sediments have been reported. For instance, in shrimp ponds, SOB were in a range of $2.3 \times 10^{2}-2.4 \times 10^{4}$ $\mathrm{CFU} / \mathrm{L}$ of water and $2.3 \times 10^{3}-2.4 \times 10^{5} \mathrm{CFU} / \mathrm{kg}$ of sediment (Rao \& Karunasagar, 2000). Devaraja et al. (2002) revealed that SOB occurred in both water and sediment of black tiger shrimp ponds treated with microbial products, in which the density in sediments was relatively low in a range of $2.5 \times 10^{3}$ $1 \times 10^{5} \mathrm{CFU} / \mathrm{kg}$. In addition, the absence of SOB in water and sediment was also reported by Abraham et al. (2004). Similarly, Abraham et al. (2015) noted that shrimp ponds receiving commercial biological products did not show any differences in SOB counts in water and sediment. It is the fact that most observations have been of the enumeration of SOB in aquaculture ponds. Most recently, some SOB strains as Thiobacillus aquaesulis, Halothiobacillus sp. have been identified in fresh water fish and brackish water shrimp ponds using molecular studies (Kumar et al., 2018; Nadella et al., 2019). However, the role of these bacteria in sulfur dynamics in aquaculture farms is still needed in further studies. In the present study, 30 isolates grew on the TSM agar, of which only five isolates were able to change $\mathrm{pH}$ of the medium and produced $\mathrm{SO}_{4}{ }^{2-}$ after inoculation in TSM broth. Therefore, it is necessary to apply the molecular study to confirm the strains and elucidate the roles of these strains in sulfur cycle in aquaculture systems in the further work.

The underlying mechanisms of removals of hydrogen sulfide by SOB have been widely documented. It is known that the decomposition of proteins during the mineralization of organic matter leads to the increase of $\mathrm{H}_{2} \mathrm{~S}$ in water and sediment. In the mechanism of how $\mathrm{SOB}$ can convert $\mathrm{H}_{2} \mathrm{~S}$ to $\mathrm{SO}_{4}{ }^{2-}$ has been proposed. To give an example, the mechanism for elemental sulfur oxidation by Acidithiobacillus ferrooxidans has been proposed as an aerobic oxidation in which the sulfur is oxidized to sulfide using oxygen as terminal electron acceptor. For this, the sulfate-cytochrome $c$ oxidoreductase containing molybdenum directly oxidizes sulfide to sulfate and the released electrons enter the respiratory chain through coenzyme and couple to oxidative phosphorylation. Several enzymes in sulfur-oxidizing system of SOB involve in oxidation of inorganic sulfur have been reported, such as sulfur dioxygenase, thiosulfate oxidase, rhodanase, and tetrathionate hydrolase etc (Holmes \& Bonnefoy, 2007; Zhang et al., 2018). In addition, sulfur oxidizing bacteria can oxidize sulfide and inorganic sulfur reduced compounds due to the production of sulfur oxidase enzyme, sulfate is formed from biological oxidation of the reduced inorganic sulfur compounds (Ravichandra et al., 2007). All the five SOB isolates were screened for the utilization of sulfide 
in in vitro conditions. There was change in color of the medium containing bromocresol purple to yellow which indicates decrease in $\mathrm{pH}$. The change in $\mathrm{pH}$ observed in the present study might be due to the utilization of sulfide and formation of sulfuric acid (Friedrich et al., 2001). In a recent study, sulfate production from thiosulfate by SOB which isolated from freshwater fish farm soil was found to be 1.42 to $1.62 \mathrm{mg} / \mathrm{L}$ (Kumar et al., 2018). The production of sulfate ion $(12.7 \mathrm{mg} / \mathrm{mL})$ and sulfur oxidase enzyme (16.6 $\mathrm{mM}$ sulfate $/ \mathrm{h} / \mathrm{mL}$ ) was produced during growth of sulfur oxidizing bacteria isolated from mid-culture intensive shrimp farms (Nadella et al., 2019). In the present work, the sulfur oxidase enzyme of isolates varied from 5.75-8.34 Units $/ \mathrm{mL}$ and the highest production of sulfate ion reached 16 $\mathrm{mg} / \mathrm{mL}$. Due to phys-biochemical traits, it is initially assumed that the SOB isolated could be the promising candidates for further studies on removal of $\mathrm{H}_{2} \mathrm{~S}$ in aquaculture ponds. However, advanced molecular studies are required in the future to elucidate the underlying mechanisms of action of SOB in benefiting hosts.

Sulfur oxidizing bacteria are ubiquitous in aquatic sediments. The SOB are primarily the gram negative bacteria (Vidyalakshmi et al., 2009). SOB consist of two groups: (i) photosynthetic/colored SOB and (ii) nonphotosynthetic/colorless SOB (Rawat \& Rawat, 2015). The colorless sulfur bacteria occur in two main forms, unicellular and filamentous. Filamentous members have conspicuous morphology and large cell size as compared to other prokaryotes. Unicellular colorless sulfur bacteria include rods (Thiobacillus, Titanospirillum), spirilli (Thiomicrospira), cocci (Thiovulum, Thiomargarita), vibrioid (Thiospira), spirochaete (Spirochaeta perfilievii) and coccoid/oval (Sulfurovum lithotrophicum) members. Two clear metabolic types exist in this group, including the chemolithoautotrophs and heterotrophs. Obligate chemolithoautotrophic colorless sulfur bacteria obtain energy by oxidizing inorganic sulfur compounds and use $\mathrm{CO}_{2}$ as carbon source; they cannot utilize organic compounds as energy source. Members of genera Thiomicrospira, Acidithiobacillus, Halothiobacillus, Thermithiobacillus, Thioalkalimicrobium and Thiohalomonas. Thioalkalivibrio thiocyanoxidans, Thioalkalivibrio paradoxus are alkaliphilic obligate chemoautotrophs. Facultative chemolithotrophs can grow either autotrophically with an inorganic energy source and $\mathrm{CO}_{2}$, or heterotrophically by utilizing complex organic compounds as both carbon and energy source. Many species of genus Thiobacillus are facultative autotrophs (Rawat \& Rawat, 2015). The genus Thiobacillus comprises of a wide range of Gram-negative, nonspore-forming, rod shaped, colorless chemolithoautotrophic sulfur bacteria (Kumar et al., 2020). Some of which are motile (Robertson \& Keunen, 2006). Interestingly, SOB can be isolated from habitats with temperatures ranging from $4-95{ }^{\circ} \mathrm{C}$. Colorless sulfur bacteria encompass members thriving at neutral, acidic and alkaline conditions with majority of well-studied members belonging to neutral pH range (Rawat \& Rawat, 2015). The differentiation of the genera of sulfur oxidizing rod-shaped bacteria is shown in Table 2 (Kelly et al., 2005). In this study, all isolates were rod-shaped bacteria with Gram negative, non-motility, non-spore forming, non-hydrogen sulfide $\left(\mathrm{H}_{2} \mathrm{~S}\right)$-producing. The $\mathrm{pH}$ range for growth was from 4 to 9 (maximal $\mathrm{pH}$ tested) grew better at temperature of $30{ }^{\circ} \mathrm{C}$. These properties indicated that the isolates are closest with their relatives Thiobacillus or Halothiobacillus genus. However, genetic studies are required to confirm screened isolates for further characterizations.

\section{CONCLUSION}

A total of 30 isolates grew on the thiosulfate agar medium, of which 5 isolates reduced the $\mathrm{pH}$ of the growth medium and showed high sulfur oxidase activity and production of sulfate ion when isolates were inoculated with thiosulfate as a substrate. The isolates TB 1.1 and TB6.2 could be promising SOB for further applied research in aquaculture. It is thought that further understanding of the molecular characterization of the screened SOB is imperatively needed to provide better strategies in selection of SOB for water treatment in aquaculture.

\section{ACKNOWLEDGMENT}

This study is funded in part by the Can Tho University Improvement Project VN14-P6, supported by a Japanese ODA loan.

\section{REFERENCES}

Abraham, T. J., Ghosh, S., Nagesh, T. S., \& Sasmal, D. (2004). Distribution of bacteria involved in nitrogen and sulphur cycles in shrimp culture systems of West Bengal, India. Aquaculture, 239, 275-288. https://doi.org/10.1016/j.aquaculture.2004.06.023

Abraham, T. J. S., Ghosh, S., Nagesh, T. S., \& Sasmal, D. (2015). Assessment of nitrogen and sulphur cycle bacteria and shrimp production in ponds treated with biological products. Journal of Coastal Life Medicine, 3, 466-470. https://doi.org/10.12980/jclm.3.2015jclm-2014-0076 
APHA, WEF, \& WWA (2017). Standard methods for the examination of water and wastewater, 23rd edition. American Public Health Association. Washington DC 20005.

Aroca, G., Urrutia, H., Oyarzun, P., Arancibia, A., \& Guerrero, K. (2007). Comparison on the removal of hydrogen sulfide in biotrickling filters inoculated with Thiobacillus thioparus and Acidithiobacillus thiooxidans. Electronic Journal of Biotechnology, 10(4), 514-520. https://doi.org/10.2225/vol10-issue4fulltext-6

Barbosa , L., Atkins, S. D., Barbosa, V. P., Burgess, J. E., \& Stuetz, R. M. (2006). Characterization of Thiobacillus thioparus isolated from an activated sludge bioreactor used for hydrogen sulfide treatment. Journal of Applied Microbiology, 101, 1269-1281. https://doi.org/10.1111/j.1365-2672.2006.03032.x

Boyd, C. E. (2015). Water quality: an introduction. Springer Publisher. https://doi.org/10.1007/978-3030-23335-8

Brenner, D. J., Krieg, N. R., Staley, J. T., \& Garrity, G. M. (2005). Bergey's Manual of Systematic Bacteriology $2^{\text {nd }}$ edition, volume 2: The Proteobacteria. Part C: The Alpha-, Beta-, Delta-, and Epsilonproteobacteria. Springer Publisher, New York.

Brennan, D., Clayton, H., \& Be, T. T. (2000). Economic characteristics of extensive shrimp farms in the Mekong Delta. Aquaculture Economics and Management, 4(3-4), 127-139. https://doi.org/10.1080/13657300009380265

Cheng, A. C., Shiu, Y. L., Chen, B. J, Huynh, T. G., \& Liu, C. H. (2016). Isolation and identification of pathogenic bacterium Aeromonas veronii from ornamental shrimp Caridina cf. babaulti. Journal of Fishery Society of Taiwan, 43, 273-283. https://doi.org/10.29822/JFST.201612_43(4).0005

Chien, Y. H. (1992). Water quality requirements and management for marine shrimp culture. In J. Wyban, (Ed.). Proceedings of the special session on shrimp farming (pp. 144-156). World Aquaculture Society.

Devaraja, T. N., Yusoff, F. M., \& Shariff, M. (2002). Changes in bacterial populations and shrimp production in ponds treated with commercial microbial products. Aquaculture, 206, 245-256. https://doi.org/10.1016/S0044-8486(01)00721-9

Food and Agriculture Organization [FAO]. (2020). The state of world fisheries and aquaculture 2020. Sustainability in action. https://doi.org/10.4060/ca9229en

Friedrich, C. G., Rother, D., Bardischewsky, F., Quentmeier, A., \& Fischer, J. (2001). Oxidation of reduced inorganic sulfur compounds by bacteria: emergence of a common mechanism? (Mini review). Applied and Environmental Microbiology, 67, 2873-2882. https://doi.org/ 10.1128/aem.67.7.2873-2882.2001

Fry, J. C. (1987). Functional roles of the major groups of bacteria associated with detritus. In D. J. W. Moriarty
\& R. S. V. Pullin (Eds.), Detritus and Microbial Ecology in Aquaculture (pp. 83-122). ICLARM Conference Proceedings, Manila, Philippines.

Fuller, R. (1989). Probiotics in man and animals. Journal of Applied Bacteriology, 66, 365-378. https://doi.org/10.1111/j.1365-2672.1989.tb05105.x

Guarner, F., \& Schaafsma, G. J. (1998). Probiotics. International Journal of Food Microbiology. 39, 237-238. https://doi.org/10.1016/s0168-1605(97)00136-0

Holmes, D. S., \& Bonnefoy, V. (2007). Genetic and bioinformatic insights into iron and sulfur oxidation mechanisms of bioleaching organisms. In D. E. Rawlings \& D. B. Johnson (eds), Biomining. Springer. https://doi.org/10.1007/978-3-540-34911-2_14

Hucker, G. J., \& Conn, H. J. (1923). Methods of Gram staining. New York State Agricultural Experiment Station.

Jaffer, Y. D., Kumar, H. S, Vinothkumar, R., Irfan, A. B., Ishfaq, N. M., Ganie, P. A., Bhat, R. A. H., \& Vennila, A. (2019). Isolation and characterization of heterotrophic nitrification-aerobic denitrification and sulfur-oxidizing bacterium Paracoccus saliphilus strain SPUM from coastal shrimp ponds. Aquaculture International, 27, 1513-1524. https://doi.org/10.1007/s10499-019-00407-0

Jahangiri, L., \& Esteban, M. A. (2018). Administration of probiotics in the water in finfish aquaculture systems: a review. Fishes, 3(3), 33. https://doi.org/10.3390/fishes3030033

Kantachote, D., Charernjiratrakul, W., Noparatnaraporn, N., \& Oda, K. (2008). Selection of sulfur oxidizing bacterium for sulfide removal in sulfate rich wastewater to enhance biogas production. Electronic Journal of Biotechnology, 11(2), 107-118. https://doi.org/ 10.2225/vol11-issue2-fulltext-13

Kelly, D. P., Wood, A. P., \& Stackebrandt, E. (2005). Genus II Thiobacillus, Beijerinck 1904. In D. J. Brenner, N. R. Krieg, J. T. Staley, \& G. M. Garrity (Eds.), Bergey's Manual of Systematic Bacteriology (Part C) (pp. 764-769). Springer.

Krishnani, K. K., Gopikrishna, G., Pillai, S. M., \& Gupta, B. P. (2010). Abundance of sulphur-oxidizing bacteria in coastal aquaculture using soxB gene analyses. Aquaculture Research, 41, 1290-1301. https://doi.org/10.1111/j.1365-2109.2009.02415.x

Kumar, N. R., Archana, K. K., Basha, K. A., Muthulakshmi, T., Joseph, T. C., \& Prasad, M. M (2018). Isolation and identification of sulphur oxidizing bacteria from freshwater fish farm soil. Fishery Technology, 55, 270-275. https://doi.org/10.22438/jeb/40/3/MRN-914

Li, Q., Wang, C., Li, B., Sun, C., Deng, F., Song, C., \& Wang, S. (2012). Isolation of Thiobacillus spp. and its application in the removal of heavy metals from activated sludge. African Journal of Biotechnology, 11(97), 16336-16341. https://doi.org/10.5897/AJB12.607 
Lilly, D. M., \& Stillwell, R. H. (1965). Probiotics: Growth promoting factors produced by microorganisms. Science, 147(3659), 747-748. https://doi.org/10.1126/science.147.3659.747

Mayer, E., Santos, G. A., \& Encarnaçao, P. (2020, July 28). Do probiotics work in aquaculture? https://www.aquaculturealliance.org/advocate/doprobiotics-work-in-aquaculture/?headlessPrint=AAAAAPIA9c8r7gs82oWZBA

Moriarty, D. J. W. (1997). The role of microorganisms in aquaculture ponds. Aquaculture, 151, 333-349. https://doi.org/10.1016/S0044-8486(96)01487-1

Moriarty, D. J. W. (1998). Control of luminous Vibrio species in penaeid aquaculture ponds. Aquaculture, 164(1-4), 351-358. https://doi.org/10.1016/S00448486(98)00199-9

Nadella, R. K., Vaiyapuri, M., Kusunur, A. B., Joseph, T. C., Velayudhan, L. K., \& Mothadaka, M. P. (2019). Isolation and characterization of sulphur oxidizing bacteria (Halothiobacillus sp.) from aquaculture farm soil. Journal of Environmental Biology, 40(3), 363-369. https://doi.org/10.22438/jeb/40/3/MRN-914

Oddsson, G. V. (2020). A definition of aquaculture intensity based on production functions-The aquaculture production intensity scale (APIS). Water, 12(3), 765. https://doi.org/10.3390/w12030765

Rao, S., \& Karunasagar, I. (2000). Incidence of bacteria involved in nitrogen and sulphur cycles in tropical shrimp culture ponds. Aquaculture International, 8(5), 463-472. https://doi.org/10.1023/A:1009250004999

Ravichandra, P., Mugeraya, G., Rao, A. G., Ramakrishna, M., \& Jetty, A. (2007). Isolation of Thiobacillus sp from aerobic sludge of distillery and dairy effluent treatment plants and its sulfide oxidation activity at different concentrations. Journal of Environmental Biology, 28(4), 819-823.
Rawat, R., \& Rawat, S. (2015). Colorless sulfur oxidizing bacteria from diverse habitats. Advances in Applied Science Research, 6(4), 230-235.

Reiner, K. (2018, July 22). Catalase Test Protocol. https://asm.org/Protocols/Catalase-Test-Protocol

Robertson, L. A., \& Kuenen, J. G. (2006). The Genus Thiobacillus. In M. Dworkin, S. Falkow, E. Rosenberg, K.H. Schleifer, E. Stackebrandt (Eds), The Prokaryotes. Springer. https://doi.org/10.1007/0-38730745-1_37

Shields, P., \& Cathcart, L. (2018, July 22). Oxidase test protocol. https://asm.org/getattachment/00ce86398e76-4acb-8591-0f7b22a347c6/oxidase-test-protocol-3229.pdf

Somsiri, T., Oanh, D. T. H., Chinabut, S., Phuong, N. T., Shariff, M., Yusoff, F. M., \& Teale, A. (2006). A simple device for sampling pond sediment. Aquaculture, 258(1-4), 650-654. https://doi.org/10.1016/j.aquaculture.2005.06.036

Ullah, I., Jilani, G., Haq, M. I., \& Khan, A. (2013). Enhancing bioavailable phosphorous in soil through sulphur oxidation by Thiobacilli. British Microbiology Research Journal, 3(3), 378-392. https://doi.org/10.9734/BMRJ/2013/4063

Vietnam Association of Seafood Exporters and Producers [VASEP] (2020). Review on Vietnam Aquaculture. Retrieved August 12, 2020, from http://vasep.com.vn/1192/OneContent/tong-quannganh.htm (in Vietnamese).

Vidyalakshmi, R., Paranthaman, R., \& Bhakyaraj, R. (2009). Sulphur oxidizing bacteria and pulse nutrition - A review. World Journal of Agricultural Sciences, 5(3), 270-278.

Zhang S., Yan, L., Xing, W., Chen, P., Zhang, Y., \& Wang, W. (2018). Acidithiobacillus ferrooxidans and its potential application (review). Extremophiles, 22, 563-579. https://doi.org/10.1007/s00792-018-1024-9 